\title{
主体的・対話的で深い学びの具現化に寄与する評価の研究 一回収箱モデルを用いた教員と生徒によるルーブリックの作成一
}

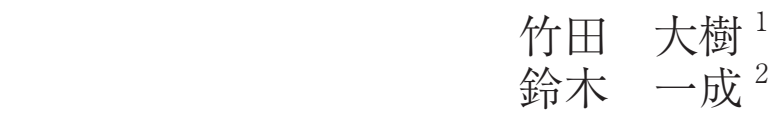

【要約】

学習指導要領が目指す主体的・対話的で深い学びの実現に向けて, 中学校理科においては 探究の過程を踏まえた生徒の目的的な学習活動が肝要であることが先行研究から指摘されて いる。この経緯から, 問題解決的な学習の枠組みにおいてルーブリックを用いたパフォーマ ンス評価が有用であることが既にわかっている。この学びの十全な実施には, 教員と生徒の 間で共有化されたルーブリックの構築が必要である。本研究では, 中学校理科において, 回 収箱モデルを用いて教員と生徒がルーブリックの作成に取り組むことで, 目的的な学習活動 の実現可能性に焦点を当て，検証を行った。具体的には，鈴木（2014）の問題解決的な学習 の枠組みにおいてルーブリック作成を取り入れた問題解決的学習の実践とその分析を行うこ とにより，教員と生徒によるルーブリック作成に関する視点の構築と目的的な学習活動の具 現化に関する考察を行った。実践では，回収箱モデルを用いて教員と生徒でルーブリック作 成に双方向的に取り組み，これをパフォーマンス評価のために運用することで，生徒の主体 的・対話的で深い学びが具現化された。回収箱モデルを用いたルーブリックの作成は, 主体 的・対話的で深い学びの実現に寄与する評価のひとつのモデルケースとなり得ると考えら れる。

[キーワード] ルーブリック，回収箱モデル，主体的・対話的で深い学び

\section{1. 研究の背景および目的}

文部科学省は 2021 年度から本格的に施行する中学 校学習指導要領を示した。この学習指導要領におい ては, 資質・能力の育成を目的とした主体的・対話 的で梁い学びの視点からの授業改善が求められてい る。この学びでは, 一連の問題解決的な探究の過程 (課題の把握, 探究, 解決) を踏まえた学習であるこ とが示された（文部科学省，2017）。これは具体的な 理科授業においては鈴木（2014）に示された理科授 業デザインのような問題解決的な学習活動の視点を 取り入れた授業を実践することが必要であると考え られる(鈴木, 2019)。

鈴木 (2014) の問題解決的な学習では, 生徒の学 習活動の具現化を支援するために, パフォーマンス 評価を活用している。パフォーマンス評価は, 紙媒

\footnotetext{
1 慶應義塾湘南藤沢中等部・高等部

2 東洋大学
}

体のテストのような単純な採点方式ではなく, 子供の 学習の総体に対する評価である (Perkins et al., 1995 ; 寺嶋・林，2006；鈴木，2014など）。これを用いる ことで目的的な学習活動が可能となり, 主体的・対 話的で深い学びに寄与できるものと捉えられる。

また，教員が必要に応じて適切なアセスメントを 施しながら学びを構成主義的にデザインすることは, 子供が学習に対する動機や認知, 行動を調整しな がら知識構築が可能となると示している（森本・鈴 木・渡辺・松本, 2014)。渡辺・森本 - 小湊 (2016) では, 構成主義的な理科授業においては生徒の学習 活動を具現化するための形成的アセスメントの重要 性を指摘している。

これらの研究に鑑みると, パフォーマンス評価は, 問題解決的な学習の具現化を支援する重要な教授学 習活動の視点であると捉えられる。しかしながら， パフォーマンス評価の基準は，知識を問うテストの ように正解が一意に定まるものではなく，連続的な 
学習を多角的に評価するために, 構築することが容 易ではないことが報告されている（松下，2007）。

そこで，パフォーマンス評価を十全に実施するに は, 学習課題に対して, どのような観点で評価され, どの程度まで課題を達成することが必要なのかを明 示したルーブリックを構築することが有用であると 指摘されている（松下, 2007 ; スティーブンス \&レ ヴイ, 2014 ; 鈴木, 2014 など)。鈴木（2011）では, 大学でのセミナーに参加した中学生を対象に, ルー ブリックの提示で生徒に及ぼす影響について調査し た。その結果, ルーブリックに示された内容が具体 的で, 生徒に理解・納得のしやすいものが, 学習内 容に対する内発的動機付けや学習方略に対して正の 効果が大きいことを示した。松下（2007）は, ルー ブリックを個々の生徒のパフォーマンスの質を図る ためのツールの一つであると示した。つまり, 問題 解決的な学習において生徒の学習活動を実現するた めには, 課題に対する明確で, 教員と生徒の間で共 有化されたルーブリックを構築することが不可欠で あると考えられる。

大学生を対象に, 問題解決的な学習において「何 を目指して, 何をやっているか」という課題意識を 明確にすることを目的として, 学生がルーブリック 構築に関与する研究では, 学生の自己評価からルー ブリック構築によって学習目標が明確になることが 示された (寺嶋・林, 2006)。さらに, スティーブン ス\&レヴィ (2014) は，授業においては，ルーブリッ ク構築時に教員と生徒が双方向的に視点を作り上げ ることで, 学習過程において生徒自身が主人公であ る自覚を高めることができることを示唆している （スティーブンス\&レヴィ，2014）。

まとめると, パフォーマンス評価を実施するため には, 学習活動が明確になったルーブリックを教員 と生徒で共有することが重要であり, 教員と生徒の 間でルーブリックを構築し, 双方向的な視点をつく りあげることで, 目的的な学習活動が達成されるこ とが期待される。これにより, 問題解決的な学習が 具現化され, 主体的・対話的で深い学びに寄与でき ると考えられる。換言すれば, ルーブリックを用い てパフォーマンス評価を実践することにより, 理科 における主体的・対話的で深い学びに寄与すること を意味している。

塚本・清水 (2006) では, 中学校理科の授業にお いて, 教師と子供が共同してルーブリックを作成し た。その結果, ルーブリック作成に携わった生徒は, そうでない生徒に比べより高い水準で学びを深めて おり, 学習結果に対する自信も統制群に比べ高いこ
とが示された。

このように, 教員と生徒がルーブリックを双方向 的な視点で構築し，パフォーマンス評価を実践する ことが主体的・対話的で深い学びに寄与できること は明らかである。しかしながら，塚本・清水 (2006) は，ルーブリック作成の理論的な方法に関する検討 はなされておらず，作成の詳細な視点を明らかにす ることは今後の授業実践を行う上で有益な知見と考 えられる。そこで本研究では, 鈴木（2014）の理科 授業デザインの枠組みを用いた問題解決的な学習に おいて，スティーブンス\&レヴィ（2014）のルーブ リック作成に関する理論を援用し，教員と生徒で ルーブリックを作成する視点を明らかにし，授業分 析をする。また，ルーブリックの作成を取り入れる 事で, 科学概念の構築に寄与するような主体的・対 話的で梁い学びが実現できているかを検討する。

\section{2. 理論的背景}

\section{1 ルーブリックの意味内容}

ルーブリックは, 学習課題に対して観点（次元） と尺度からなる記述語を用いた表形式の評価指標で, 教員が生徒に対して期待する活動や獲得するべき能 力の方針を含まれており，教員と生徒の双方の到達 目標を明確にし, 到達目標の達成度や理解度の認識 やそれに伴う省察・振り返りなどを促す効果が期 待される（松下，2007；スティーブンス＆レヴィ, 2014 ; 鈴木, 2014)。

一般にルーブリックでは, それぞれの評価の観点 の $\mathrm{A}$ 評価から $\mathrm{C}$ 評価に対して尺度が示されている。 鈴木（2014）では, ルーブリックを授業に取り入れ ることのメリットとして, 以下の三点を挙げている。

- 子供の課題への取り組みが, 子供側の誤解や理 解不足によって評価に繋がらない事態を回避可 能で, パフォーマンス評価を実践し, 子供のパ フォーマンスを引き出すことができる。

・ 子供が興味や関心を持って学習に取り組み, 子 供の学習に対する主体性の認識を強化させる。

・評価基準を子供にも作成させることにより, 形 成的アセスメントとして運用することができる。 これにより, 学習活動を通じて常に変化し続け る子供の概念構築過程に対して, 教員が子供に 即時的にフィードバックできる。

つまり, ルーブリックを用いることで, 生徒のパ フフォーマンスを引き出し, 動機付けを促進すると ともに, 即時的なアセスメントを可能にするなど, 問題解決的な学習活動の質的向上が期待されると考 えられる（鈴木, 2014 ; 渡辺ら，2016）。 


\section{2 ルーブリックの作成方法とそのモデル}

ルーブリック作成手順としては，スティーブンス \&レヴィ（2014）の手法が有用である。この手法に おいては，ルーブリック作成に関して生徒が参加し てかつ具体的手順の複数のモデルが示されており, 生徒が関与するレベルを選択することができる。生 徒をルーブリック作成に関与させることで, ルーブ リックの教員と生徒の間での共有化が期待される。

スティーブンス\&レヴィ（2014）の方法は, 教員 が全て作成する場合や教員と生徒と共に作成する場 合があるが，どの場合においても，四つの基本的な 段階の存在を示した。以下，その四段階を概観する。

- 学習課題の共有 (第 1 段階) : 生徒に何を求め ているのか, なぜこの課題を作ったのか, 生 徒に期待することは何かを教員から述べる。

リストの作成（第 2 段階）：課題の具体内容と 課題が完成した際にできるようになって欲し いものを絞る。

・ グループ化と見出し付け（第 3 段階）：課題に 期待する様々な事項をグループ化する。各グ ループに見出しをつける。

ルーブリックの完成（第 4 段階）：第 3 段階で 得られた評価観点を，教員がルーブリックの 形式に当てはめ完成させる。

生徒と協働したルーブリック作成モデルは, 生徒 がどの程度ルーブリックの作成に関与するかによっ て, 提示モデル, フィードバックモデル，ポスト イットモデル, 回収箱モデルに分類されている。本 研究では, 教員と生徒が双方向的に意見を反映させ ることができる回収箱モデルを用いた。

回収箱モデルとは, 授業時間内でルーブリックを 生徒自身に作成させるモデルである。このモデルで は，教員が学習課題にはどのようなことが求められ ているかを説明した後, 生徒はどのようなことがで きればいいのかを検討し, 評価の具体的な視点（記 述語）を作成する。特にリストの作成（第 2 段階), グループ化と見出し付け（第 3 段階）について, 生 徒に深く関与させる方法である。

したがって, 学習課題に対して, 生徒に最大限の 柔軟性と創造性を発揮する機会を与えることができ る。その上，生徒の意見を取り入れた上で，最終的 なルーブリックの調整は教員が行うため, カリキュ ラム適合性（Gipps, 1995）を担保することもできる モデルと考えられる。このモデルにより, 教員と生 徒がルーブリック作成に取り組むことで，ルーブ
リックの記述語で示された文脈の意味の解釈を共有 化でき，生徒自身が目的的な学習活動ができると考 えられる。

一般に，生徒がルーブリックの作成に参加する場 合，授業において課題に対して教員からの十分な説 明を行う必要性がある（スティーブンス\&レヴィ， 2014）。すなわち，教員からの「なぜこの課題を学習 するのか?」といった説明である。教員の説明を踏 まえて，生徒は「どのような作業が必要か」,「どの ようなことを目標として揭げれば良いか」,「何を もって学習の到達とするか」を議論し，これらを踏 まえてルーブリックを構築していくことになる。

問題解決的学習の実施には, 学習の見通しを持つ ことが重要である。回収箱モデルを用いることで, 生徒が自身の学習活動を想定しながらルーブリック 作成に取り組むことができると考えられる。これは 学習に対する見通しを持つことと同意義で, 探究の 過程を踏まえた問題解決的学習を駆動することがで きると予想される。

\section{3. 授業実践の全体像}

\section{1 実践の目的}

生徒がルーブリック作成に取り組むことは, 生徒 に今後の学習活動を想起させ，学習活動へ見通しを 持つことに繋がると考えられる。また，教員がその 取り組みに関わることで, ルーブリックに教員権限 も含ませられる。これらにより，生徒と教員の間で 共有化されたルーブリックが完成すると予想される。 したがって, パフォーマンス評価を用いた問題解決 的な学習において，回収箱モデルによるルーブリッ ク作成を取り込んで，主体的・対話的で深い学びが 実現できたかについて，生徒が作成したポートフォ リオや質問紙調査を分析した。実践は，鈴木 (2014) の理科授業デザインの枠組みを用いた（理科授業デ ザインの枠組みについては鈴木（2014）を参照）。

主体的・対話的で深い学びの実現には, 学習活動 や学習目的の焦点化が重要である。ルーブリックは, 学習活動や学習目的を明確するために必要なツール である。ルーブリックを用いてパフォーマンス評価 を実施することができれば，学習活動の具現化がで きると考えられる。言い換えれば，ルーブリックに 記載された具体的な学習活動を生徒が行い, 科学概 念の構築に寄与することができていれば, ルーブ リックを共有し，主体的・対話的で深い学びが実現 できたものと考えられる。

したがって，本論文では，ルーブリックが共有で きたかについては，ルーブリック記載の焦点化され 
た学習活動が具現化できたかどうかで判断した。ま た，主体的・対話的で深い学びの実現に関するクラ イテリアは，竹田・鈴木（2020）を援用し，作成し たルーブリックを用いた問題解決的な学習を十全に 実施し, 生徒の作成したポートフォリオから科学概 念の構築が認められることを, 本研究においての主 体的・対話的で深い学びの具現化のクライテリアと する。

\section{2 実践の概要}

実践時期は 2017 年 7 月の全 5 回の授業を通じて 行った。実践対象は私立中学校第 3 学年 168 名であ る。単元は, 「化学変化とイオン」の「酸, アルカリ とイオン」である（表 1)。中和反応の実験を通じて イオンモデルを用いてその仕組みを解き明かすため の問題解決的な学習を目指し, 実験の目的を「中和 の仕組みと量的関係について理解する」とした。こ れは, 酸とアルカリの性質について, 中和に関する 実験を行い, 酸とアルカリを混ぜると水と塩が生成 することを理解させるとともに, 中和反応の本質で ある量的関係，すなわち，酸・アルカリの価数やその 濃度，体積を概念として理解することを意図している。

生徒は, 酸とアルカリのそれぞれの特性が水素イ オンと水酸化物イオンによること, 物質量という定 量的な考え方を前時までに学習している。
生徒は, 直近三ヶ月以内の過去 3 回の授業実践 (化学, 地学) にて, ルーブリックを教員が提示し, それを踏まえて問題解決的な学習に取り組んだ経験 がある。したがって，ルーブリックが評価基準であ り，学習活動を具現化するためのツールであること は理解している。しかしながら, 生徒がルーブリッ クについて，作成から関与するのは本実践が初めて である。

表 1 は, 中和実験についての単元計画である。一 連の問題解決的学習に根ざした授業は, 全 5 時間で 実施した。なお，全 5 時間の中に，実験報告書を学 習の段階に応じて随時作成している。1時間目では 学習の目的を明らかにした上で, 生徒がルーブリッ クの作成に取り組んだ。2 時間目（問題把握的学習） は, 既有概念の確認とパフォーマンス課題（実験の 目的）を達成するための実験計画の作成を実施した。 3 時間目 (分析的学習) は, 生徒が実際に実験を行い, 結果のまとめを行った。 $4 \cdot 5$ 時間目（共通感覚的学 習・知識活用的学習) は, 個人の解釈を基に, 班内 での議論, 全体への発表といった言語活動を行った 上で, 最終的に解釈をまとめる際に知識活用的学習 として, 今後の展望や新たな疑問を再度まとめ, 既 有概念との結びつきや次の学習課題を見出させた。

分析は，1時間目で取り組んだルーブリック作成 のためのワークシート, 事後に実施した質問紙調査,

表 1 単元計画 酸, アルカリとイオン（全 5 時間）

\begin{tabular}{|c|c|c|c|}
\hline 時間 & 学習場面 & 学習活動 & $\begin{array}{c}\text { 理科授業デザインとの対応 } \\
\text { (鈴木, 2014) }\end{array}$ \\
\hline 1 & $\begin{array}{l}\text { 導入の演示実験 } \\
\text { 回収箱モデルを用いた } \\
\text { ルーブリックの作成 }\end{array}$ & $\begin{array}{l}\text { · 中和に関する量的関係 }(\text { 体積・濃度) について問い } \\
\text { かける演示実験を行う } \\
\text { •これからの学習活動と内容を見通して, 学習の評価 } \\
\text { 基準と到達目標を生徒と教員の双方で共有化する }\end{array}$ & \multirow{2}{*}{$\begin{array}{l}\text { 第 } 1 \text { 象限 } \\
\text { 問題把握的学習 }\end{array}$} \\
\hline 2 & $\begin{array}{l}\text { 仮説・予想 } \\
\text { 実験計画の作成 }\end{array}$ & $\begin{array}{l}\text { ·既有概念から学習についての課題の発見 } \\
\text { ·自然現象への疑問や自分の考えを持ち, 予想や仮説 } \\
\text { を立てる }\end{array}$ & \\
\hline 3 & 結果のまとめ & $\begin{array}{l}\text { ·塩酸, 硫酸, 水酸化ナトリウム水溶液 }(0.1 \mathrm{~mol} / \mathrm{L} \text { と } \\
0.2 \mathrm{~mol} / \mathrm{L}) \text { を用いて, 酸とアルカリを混合させる対 } \\
\text { 照実験を } 8 \text { パターン行い, 中和時の滴定量の結果を } \\
\text { まとめる } \\
\text { •観察・実験結果についての記述や表やグラフを用い } \\
\text { た様々な形態の情報整理を行う }\end{array}$ & $\begin{array}{l}\text { 第 } 2 \text { 象限 } \\
\text { 分析的学習 }\end{array}$ \\
\hline 5 & $\begin{array}{l}\text { 考察 } \\
\text { 話し合い } \\
\text { 発表 }\end{array}$ & $\begin{array}{l}\text { ·自然現象に対する自分の概念を, 論理性を持った解 } \\
\text { 釈を通じて表現する } \\
\text { ·話し合いや発表を行うことで, 科学的概念を構築 } \\
\text { する }\end{array}$ & $\begin{array}{l}\text { 第 } 3 \text { 象限 } \\
\text { 共通感覚的学習 }\end{array}$ \\
\hline 事後 & $\begin{array}{l}\text { 解釈のまとめ } \\
\text { 学習の振り返り }\end{array}$ & $\begin{array}{l}\cdot \text { ·第 } 1 \text { から } 3 \text { 象限の学習を振り返る } \\
\cdot \text { 構築された概念を活用して, 新しい問題解決へ望む }\end{array}$ & $\begin{array}{l}\text { 第 } 4 \text { 象限 } \\
\text { 知識活用的学習 }\end{array}$ \\
\hline
\end{tabular}


発表に用いたホワイトボードや生徒から提出された 実験報告書を対象とした（実験報告書の詳細な書式 については鈴木（2014）を参照)。報告では一名を代 表例として紹介した。なお，実験報告書は，鈴木 （2014）と同様のものを使用している。ここでは，既 有概念を用いて，実験計画を作成し，実験結果をま とめ, 解釈まで行うことができる三列のワークシー トで，学習が進行するに応じて，記載場所を移すも のになっている。なお，本実践では，ルーブリック を解釈の要点として実験報告書に記載している。

また、ルーブリックを用いた評価の観点を計画 · 結果・解釈の三つに分類している。これは, 鈴木 （2014）や竹田・鈴木（2020）と同様の方法を踏襲し ている。実験報告書において，A 評価に十分に達し ていないが, 項目が埋まっている場合は B 評価, 空 欄が多く項目が埋まっていない場合を C 評価とした。 なお，分析にあたっては，教育的鑑識眼を持った授 業者と授業に参与した理科教育の専門家によって行 い，分析の意見が一致しない場合には，ルーブリッ クを基に話し合い, 調整・統一した。

本実践では，生徒が個人レベル，班レベルでルー ブリックを，表形式のワークシートを用いて作成し た（図 1)。研究では, 生徒が作成したワークシート を分析した。ワークシートは，スティーブンス\&レ ヴィ（2014）を踏襲した順番（第1段階から第4段階）
になるよう設計し，上段には「このレポートの到達 目標は何か？」を記載させ，その下には，計画，結 果，解釈のそれぞれの段階において，左から個人の 考え $\rightarrow$ 班の考え $\rightarrow$ ラスの考えを記載する仕様と した。

班では個別のルーブリックを統合させ一つのもの を作成した。班ごとに作成したルーブリックについ て，ホワイトボードを用いて班ごとに全体へ発表さ せた。本実践は回収箱モデルを用いた作成過程の実 践と学習内容の理解であるため, これらのワーク シートを回収した。

生徒の作成したホワイトボードの資料から，教員 がルーブリック作成の取りまとめを行なった。その 際，教員は，強調された見出しに注目しながら，ルー ブリックを完成させた。

\section{4. 実践におけるルーブリックの作成}

\section{1 学習課題の共有（第 1 段階）}

1 時間目は，回収箱モデルによるルーブリック作 成に取り組んだ。まず，回収箱モデルの学習課題の 共有（第 1 段階）から始めた。

学習課題の共有（第 1 段階）では, 「生徒に何を求 めているのか」,「なぜこの課題を作ったのか」,「生 徒に期待することは何か」を教員から述べることが 重要と示している。実際にどのように指示したかに

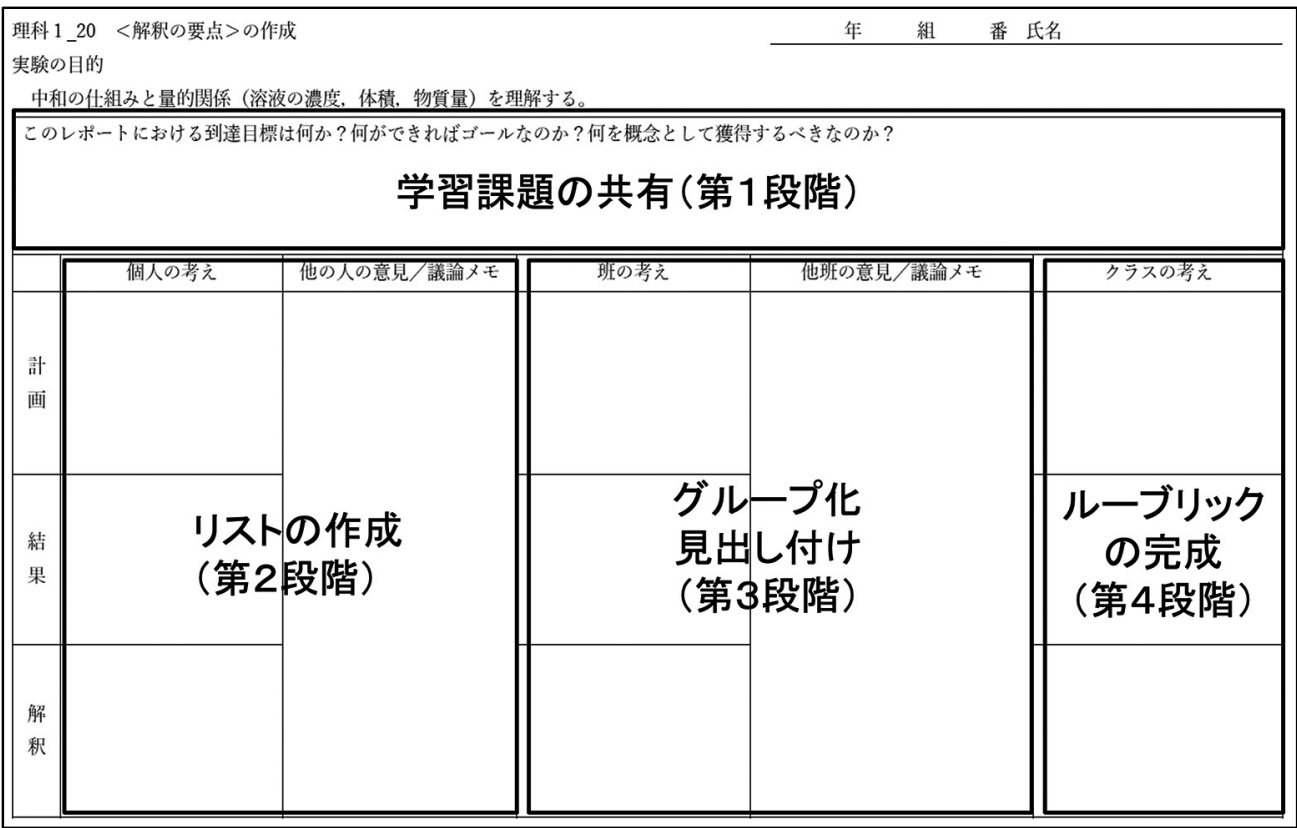

図 11 時間目のルーブリック作成で回収箱モデルにおいて用いたワークシート 
ついては，それぞれの場面で詳述する。

図1のワークシートの導入の前に, 以下のように 導入の演示実験を行った。 $10 \mathrm{~mL} の 0.1 \mathrm{~mol} / \mathrm{L}$ 水酸化 ナトリウム水溶液に BTB 溶液を入れたビーカーに, 同濃度の塩酸 $10 \mathrm{~mL}$ を入れて中和させる演示実験を 紹介した。「なぜ色変化が起こるのか」,「酸とアルカ リの量的関係はなんだろうか」といったことを発問 した。これにより,「中和」や「イオン」を引き出さ せた。「生徒に何を求めているか」については, 既習 事項である酸性水溶液とアルカリ性水溶液を用いて, 色変化を見せることで，中和という量的理解が伴う 現象を，イオンを用いて考えていくこととした。

酸・アルカリの水溶液を混合することで水と塩 ができるだけで理解を留めるのではなく, その量的 関係についても注目させるため, 教員は,「もし, $0.1 \mathrm{~mol} / \mathrm{L}$ 水酸化ナトリウム水溶液が $10 \mathrm{~mL}$ 入った ビーカーに，この塩酸を一滴だけを入れたとしたら， どうなると考えられるか? 」,「もし，2 倍量の塩酸 を入れたらどうなるか？」と発問した。これにより， 生徒は, 二者の体積関係の重要性に気がついた。ま た,「もし, 一方の濃度を変えたら, 中和するために 入れるもう一方の体積はどうなると考えられるか? とも発問し，「中和には濃度と体積が大きく関係して きており, 中和の仕組みを解明することが今回の課 題です」と投げかけた。これは, 「なぜこの課題を 作ったのか」の説明である。これにより, 濃度の観 点も視野に含ませ, 中和反応と量的関係を結びつ けた。

その上で, ワークシートの上段に, 到達目標を記 載させた（図 1)。このように, 演示実験も取り入れ ながら実験の目的の焦点化を行った（図 1)。体積と 濃度の関係を知るためには, 片方を固定して, もう 一方を変動させる対照実験が必要であることを示唆 した。これは「生徒に期待するは何か」を伝えたこ とと考えられる。

到達目標を簡単に発言で確認した後,「中和の仕組 みと量的関係について理解する」を，これからのパ フォーマンス課題（実験の目的）として提示した。 この目的を達成するためにはどのようなことが必要 かを問いかけ，全体にルーブリックを生徒が作成す る旨を伝えた。

\section{2 リストの作成（第 2 段階）}

リストの作成（第 2 段階）では, 課題の具体内容 と課題が完成した際にできるようになって欲しいも のを絞ることが重要である。そこで, 教員は生徒に 対して，「これからルーブリックの作成に入ります。
実験の目的は, 中和の仕組みと量的関係について理 解することです。この目的を達成するためには, 計 画・結果・解釈のそれぞれの学習段階で, どのよう な具体的な学びが必要だと考えられますか? あなた が大事だと思うことを文章として書いてください。 過去に扱ったルーブリックを参考にしても構いませ ん。」と指示した。これを踏まえて, 生徒自身が, 計 画・結果・解釈のそれぞれの欄に, 詳細なルーブ リックの作成を, 十分程度で個人の考えとしてワー クシートの左側に観点別にまとめた（図 1)。十分 後, それぞれの項目を埋め切れていない生徒も若干 いたが，概ね生徒はしっかり取り組んでいた。

その後, 教員は生徒に対して,「個人の考えたルー ブリックを基にして, 班でお互いに発表しあって, それぞれの観点でどういう部分が大事かを焦点化し てください。」と指示した。生徒が作成したルーブ リックについて, 班単位（4 人程度）でお互いに発 表し合った。次に, 各観点について重要だと思われ る要素についての話し合いを行わせ, ルーブリック の核となる要素を焦点化させた。ここでは, 各班の 考えをホワイトボードにまとめる作業を行ったこと により，図 1 下段の 2 列目他の人の意見 /議論メモ は, 多くの生徒が記述していた。

\section{3 グループ化と見出し付け（第 3 段階）}

それぞれの項目に対して班で一つのルーブリック を構築させた。その後, 全体発表のためのホワイト ボードの作成に取り組んだ（図 2)。

ここでは，グループ化と見出し付け（第 3 段階） では, 課題に期待する様々な事項をグループ化する。 各グループに見出しをつけることが肝要である。

各班が作成したホワイトボードの, 特に重要な要

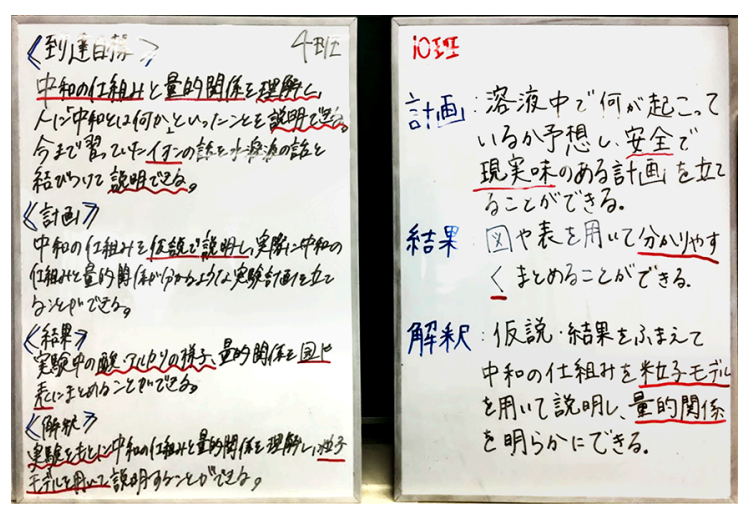

図2 生徒が作成したルーブリックの発表資料（ホワイ トボード)。重要な見出しは下線で強調した。 
素を赤線で強調し, 見出し付けするように教員が指 示した。例えば, 図 2 左〈到達目標〉と〈計画〉に おいては,「中和の仕組みと量的関係を理解し」,「仮 説で説明し」とある。これは, 計画において, イオ ン概念や薬品の分量も考慮しながら, 中和の原理に ついて仮説を立てる事を重要視していることがわ かった（図 2)。見出しをつけた状態の班で作成した ルーブリックを, ほとんどの生徒は図 1 下段 3 列目 の班の考えの欄に, 記入していた。

表 2 は,このような過程を経て, ルーブリックの 作成において, 生徒が重視した見出しを, 教員がま とめたものである。仮説・予想・計画の立案につい て, 多くの班（34 班／44 班）が同様の考え方を示 していた（表 2, 計画の観点の見出し，「仮説・予 想・計画の立案」部分)。

また，仮説を立てるための足がかりとして「授業 の演示実験を基に」するという発想や, 理科におい て重要事項である「安全性」についての言及も見ら れた。

表 2 の結果の項目では, 「図や表」を用いることを 多くの班が重視していた（36 班／44 班）。また, 結 果についての具体的な記述として,「指示薬の色変 化」「水溶液の様子の観察」が挙げられた。これに より,「液性の変化」の考察や比較を行いたい意思が くみ取れた。また，「グラフ」などで表現するため に, 使った試薬などの体積や物質量などを「数字化」 することも言及された（表 2)。教員が事前に用意し たものでは「濃度と体積の関係性」としていたが, 「量的関係」とした。

解釈の項目では,「イオンモデル」,「化学反応式」 といった, 最終的なまとめに必要と考えられるもの が挙げられた。また, 実験を通じて「量的関係の法 則性」を見いだしながら,「誤差要因」などにも言及 があった。

\section{4 ルーブリックの完成（第 4 段階）}

1 時間目の最後に, ルーブリックの完成（第 4 段 階）に移った。ここでは，第 3 段階で得られた評価 観点を, 教員がルーブリックの形式に当てはめ完成 させることが大事である。1 時間目終盤では，ホワ イトボードを用いた発表を各班が行った。その後, 各班のホワイトボードをすべて黒板の前に並べた。 教員は各班のホワイトボードで示された見出し（図 2，ホワイトボードの赤線）を抜き出しながら，ルー ブリックにおいて重要となる点について, 学級内で 共有した。

具体的には，ホワイトボードの記述を全体の前で 俯瞰的に取り上げ，教員から，簡単にグループ化や 更なる見出し付けを行った。これにより，生徒と ルーブリックに盛り込む点について確認できた。回 収箱モデルを用いることで, 見出しの抽出をするこ とができ, 生徒が重要と捉える見出しを盛り込んで, 教員はルーブリックのとりまとめができた。

この段階において，生徒が重要であると考えた見 出しが, 学習指導要領や教科書に記された学習内容 の重要な部分と, 大きな差異があってはならない。 そこで, 教員が想定したこの授業における模範的な ルーブリックと比較を行った。

教員が想定したこの授業における模範的なルーブ リックとの比較を, 表 2 に示した。基本的には, 生 徒たちの見出しの内容と, 事前に教員が想定した ルーブリックと大きな違いがなかったが，細かな部 分で異なる点が見られたので，教員によって文言の 微調整が行われた。これらを俯瞰し, 改めて教員が ルーブリックを整理し完成させた過程を以下に記述 する。まず，教員が想定した事前の計画のルーブ リックには,「安全性」と「中和の原理の説明」は含 めていなかった。「安全性」については, 暗黙裡の前 提としていたため，明文化することとした。また， 「中和の原理の説明」は，中和反応そのものの理解を 確認するためにも必要と判断した。これらを補って

表 2 教員が事前に想定した模範的なルーブリックとグループ化と見出し付け（第 3 段階）において生徒が重視した 見出し

\begin{tabular}{|c|c|c|}
\hline 観点 & 事前に用意した模範的なルーブリック & グループ化と見出し付け（第 3 段階）において生徒が重視した見出し \\
\hline 計画 & $\begin{array}{l}\text { 中和実験において濃度と体積の関係を理 } \\
\text { 解するための計画を立てることができる。 }\end{array}$ & 仮説・予想・計画の立案, 中和の仕組み, 授業の演示実験を基に, 安全性 \\
\hline 結果 & $\begin{array}{l}\text { 実験結果を, 表やグラフなどを用いて, } \\
\text { わかりやすく記述できる。 }\end{array}$ & $\begin{array}{l}\text { 図や表, わかりやすさ, 結果の詳細に関する記述（観察, 実験, 正確性, } \\
\text { 比較, 数值化) }\end{array}$ \\
\hline 解釈 & $\begin{array}{l}\text { イオン概念を用いて, 中和の仕組みを説 } \\
\text { 明できる。 }\end{array}$ & イオンモデル，化学反応式，量的関係の法則性，論理的説明 \\
\hline
\end{tabular}


「中和の原理を説明し, 安全かつ液性に関する量的関 係を理解するための計画を立てることができる」と した (表 3)。

次に, 結果の項目については,「観察」は, 想定し たルーブリックには入れていなかったが, 目の前で 起きていた現象を見て，考察に繋げるためには，観 察が重要であることは自明であり, 生徒の具体的な 学習活動として追加することとした。また,「図や 表」「グラフ」といった具体的なツールを用いること を生徒が示していた。したがって，これらを鑑みて， 「実験中の様子を観察し, 表やグラフなどを用いて, 結果をわかりやすく記述できる」とした（表 3$) 。$

そして, 解釈では, 生徒の作成にあるように「イ オンモデル」や「化学反応式」を取り入れた。粒子 モデルを用いて化学反応を理解することは中学 2 年
次の学習ですでに行っており,「粒子モデル」と表現 している生徒も一部散見された。ここでは, 水溶液 中の化学反応が, イオンによるものであることが明 白であることや教科書に「イオンのモデル」との記 載があることから，「イオンモデル」をルーブリック に取り入れることにした。そして，これらを「量的 関係の法則性」に結びつけることの必要性があるた め,「イオンモデルや化学反応式などを用いて, 中和 の仕組みや量的関係を説明できる」とした（表 3$) 。$

これらを考慮に入れて，授業者と授業に参与した 理科教育の専門家によって, 検討し再構築し直した ルーブリックが表 3 である。

図 3 は, 生徒が実際に図 1 のワークシートに記入 したものの例である。ワークシートの記入に関して, 教育的鑑識眼を持った授業者と授業に参与した理科

表 3 最終的なルーブリック

\begin{tabular}{|c|c|c|c|}
\hline 観点 & A 基準 & B 基準 & $\mathrm{C}$ 基準 \\
\hline 計画 & $\begin{array}{l}\text { 中和の原理を説明し, 安全かつ液性に関する量的関係 } \\
\text { を理解するための計画立案を十分に満足している。 }\end{array}$ & $\begin{array}{l}\text { 中和の原理を説明し, 安全かつ液性に関する量的関 } \\
\text { 係を理解するための計画の立案を概ねできている。 }\end{array}$ & \multirow{3}{*}{$\begin{array}{l}\mathrm{B} \text { に達せ } \\
\text { ず, 項目 } \\
\text { が埋まっ } \\
\text { ていない } \\
\text { 場合。 }\end{array}$} \\
\hline 結果 & $\begin{array}{l}\text { 実験中の様子を観察し，表やグラフなどを用いて，結 } \\
\text { 果をわかりやすく記述する事が十分にできている。 }\end{array}$ & $\begin{array}{l}\text { 表やグラフなどを用いて, 結果を記述が概ねできて } \\
\text { いる。 }\end{array}$ & \\
\hline 解釈 & $\begin{array}{l}\text { イオンモデルや化学反応式などを用いて, 中和の仕組 } \\
\text { みや量的関係を十分に説明できる。 }\end{array}$ & $\begin{array}{l}\text { イオンモデルや化学反応式などを用いて, 中和の仕 } \\
\text { 組みや量的関係の説明を概ねできている。 }\end{array}$ & \\
\hline
\end{tabular}

\begin{tabular}{|c|c|c|c|c|c|}
\hline \multicolumn{6}{|c|}{$\begin{array}{l}\text { 理科 } 1 \_20 \text { <解釈の要点>の作成 } \\
\text { 実験の目的 } \\
\text { 中和の仕組みと量的関係（溶液の濃度，体積，物質量）を理解する。 }\end{array}$} \\
\hline \multicolumn{6}{|c|}{$\begin{array}{l}\text { このレボートにおける到達目標は何か？何ができればゴールなのか？何を概念として獲得するべきなのか？ } \\
\text { 中和kは何かて理解し、芹の方法を見フけ出す． }\end{array}$} \\
\hline & 個人の考员 & 他の人の意見／議論メモ & 6 班の考え & 他班の意見／議論メモ & クラスの考兄 \\
\hline $\begin{array}{l}\text { 計 } \\
\text { 画 }\end{array}$ & $\begin{array}{l}\text { 中和とは何かといる2と } \\
\text { を考え实際に中和させ } \\
\text { る方法を考えることが } \\
\text { できる. }\end{array}$ & \multirow{3}{*}{ 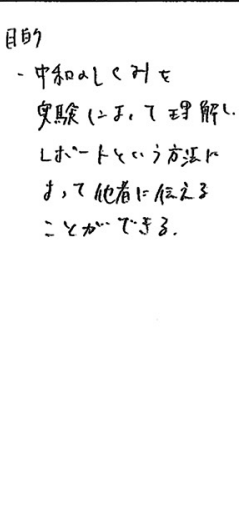 } & 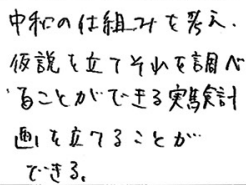 & \multirow{3}{*}{ 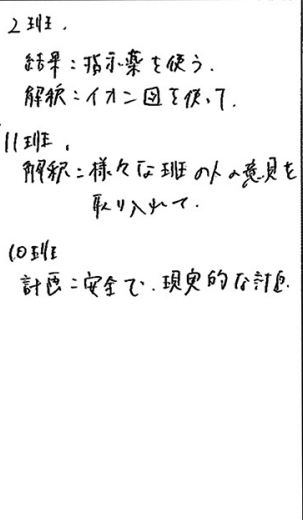 } & $\begin{array}{l}\text { 実験報告書 } \\
\text { の上部へ記載 } \\
\text { した（図 4） }\end{array}$ \\
\hline 結 & 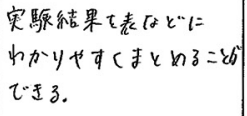 & & 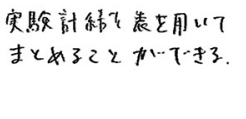 & & \\
\hline 解 & 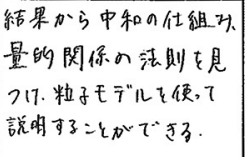 & & 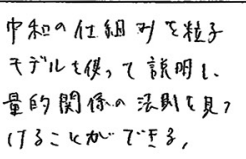 & & \\
\hline
\end{tabular}

図 3 実際に生徒が記載した図 1 のワークシートの例。完成した最終的なルーブリックは, 実験報告書の上部へ記載 した (図 4 を参照)。 


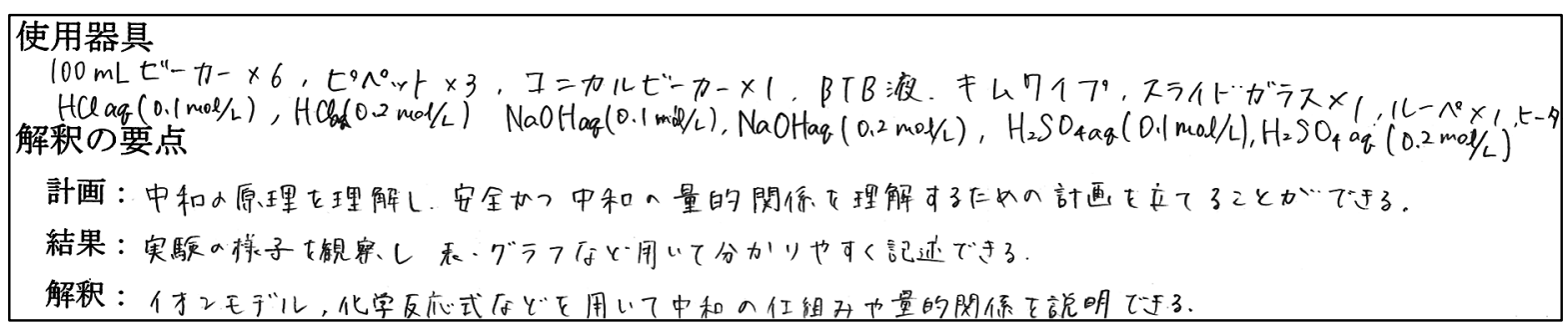

図 4 実験報告書の上部。使用器具, 解釈の要点を生徒が記載している。

教育の専門家で分析した結果, 十分満足できる記述 をした生徒は 139 名, おおむね満足できる記述をし た生徒は 21 名, 記述内容が努力を要する生徒は 2 名 であった。

このような過程を踏まえることで, 生徒が自ら目 的を外化することで, 理解しやすい表記となり生徒 と共有化することができ，教員がカリキュラムとの 整合性を確認することで学習内容が担保された, 生 徒の学習活動が具体的に明文化したルーブリックが 構築された。

ここで完成したルーブリックは，「解釈の要点」と して, 実験報告書の上部に記載し, 仮説の立案, 実 験結果の記録や解勫の各学習場面で確認し, 生徒の 目的的な学習活動を支援した（図 4)。

\section{5. ルーブリックを用いた学習活動の分析}

\section{1 実験の仮説・予想}

ルーブリックを作成した生徒が, 目的的な学習活 動を実践できたかを明らかにするために，実験の仮 説・予想, 計画の作成, 結果, 考察と発表, 解釈と まとめの各学習場面に扮いて, 生徒の記述を分析 した。

図 5 は, 実験報告書に記載された生徒の実験に対 する仮説・予想である。仮説を書かせる段階では, 「中和とは何か？どのようにして中和が起こるのか？ について書きましょう」と指示した。この記述にお いては, 中和の仕組みについて, 代表的な酸（塩酸） とアルカリ（水酸化ナトリウム水溶液）を混合させ た時に起こる反応であり, 水溶液中の水素イオンと 水酸化物イオンが結びつくことで中性になることが 示されていた。ここでは, 酸やアルカリの種類によ る中和の違いや量的関係，イオンモデルについては, 記述がなかった。

ルーブリック（表 3）の計画の観点で, 「中和の原 理の説明」とあることから, 生徒がルーブリックを 念頭に置き, 目的的な学習活動を実践した証左であ ると考えられる。

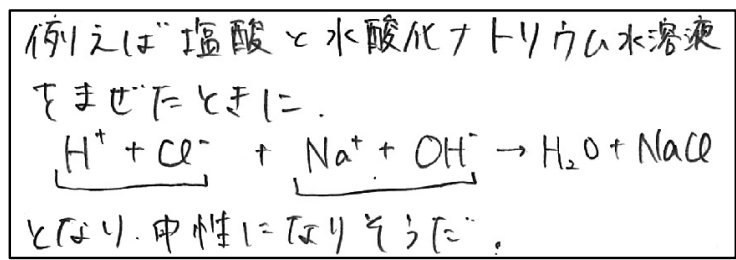

図 5 実験報告書の仮説・予想。中和の原理を酸・アル カリを決定づけるイオンの観点から説明していた。

\section{2 実験計画の作成}

実験計画の作成では，仮説・予想を基に，実験計 画を作成した（図 6)。本実験で使用可能な薬品（塩 酸, 硫酸, 水酸化ナトリウム水溶液) と器具（ビー カー, 駒込ピペットなど）は, 図 4 上部のように提 示し, 薬品の量についても検討させた。

図 6 によると, 実験計画として, BTB 溶液の色変 化を元にして，塩酸に水酸化ナトリウム水溶液を一 定量ずつ入れ，塩酸と水酸化ナトリウムが中性にな る時の量を調べる実験を計画していることがわかっ た。併せて緑色になった際の残留物についての検討 方法も記載していた。これは,ルーブリックの計 画・後半部分の「中和の量的関係を理解する」ため に必要なことであり, 学習活動の具現化につながっ たと考えられる。

また，実験の模式図として，ガラス棒につたわら せるように薬品をもう一方のビーカーに入れる描写 があった。これは，中和反応が量に関して非常に繊 細なものであることを意識しているためであり，酸 やアルカリの水溶液を取り扱う上で, 安全性に配慮 したと考えられる。すなわち, 計画のルーブリック の「安全性」に関する視点が意識されていたために 現れた記載と捉えられる。なお，計画のルーブリッ クによる評価は, $\mathrm{A}$ 評価 162 名, $\mathrm{B}$ 評価 3 名, $\mathrm{C}$ 評 価 0 名（欠席 3 名）であった。

実際には，中和反応は繊細に注意して取り組む実 験であることから, 教員は実験技能の習得として, 


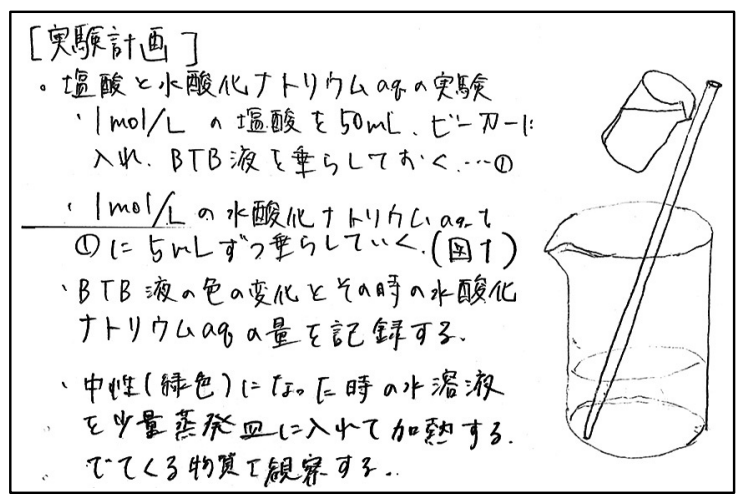

図 6 実験報告書の実験計画。計画のルーブリックに基 づいて, 安全性に配慮しながら, 指示薬の色変化 や生成物の確認を基軸にして中和を議論するため の定量的な実験ができる計画を練っていた。

慎重にビーカーを動かしながら，こまごめピペット で滴下するよう技能に関する指導をした。

\section{3 実験の結果}

3 時間目は, 実験を行った。実験は, 塩酸, 硫酸, 水酸化ナトリウム水溶液について, それぞれ $0.1 \mathrm{~mol} / \mathrm{L}$ と $0.2 \mathrm{~mol} / \mathrm{L}$ の濃度のものを用意し, ビーカー, コニ カルビーカー, 駒込ピペット, BTB 溶液を使用した。 生徒は班単位で濃度と体積の関係が明らかになるた めの対照実験ができるように, 1 種類の酸・アルカ リを混合させる 8 パターンの組み合わせについて， 対照実験を行わせた。

図 7 は, 生徒が記述した実験の結果で, 酸性水溶 液（塩酸, 硫酸）とアルカリ性水溶液（水酸化ナト リウム水溶液）の組み合わせと, 中性になった時の 溶液量（体積, モル濃度）を, 表を用いてまとめた 記述である。図 7 の結果（1）から（8）は, 塩酸, 硫酸, 水酸化ナトリウム水溶液（それぞれ $0.1 \mathrm{~mol} / \mathrm{L}$ と $0.2 \mathrm{~mol} / \mathrm{L})$ を混合させる 8 パターンについて行い,

（9）から（12）の結果については, これらのパター ンの中で予想と反したものについて, 班で検討し, 再実験を行っていた。

生徒は, 実験結果を, 記録し始めた当初は数字の 羅列のようにまとめていた。例えば，水酸化ナトリ ウム水溶液 $(0.1 \mathrm{~mol} / \mathrm{L}) 5 \mathrm{~mL}$ に, 塩酸 $(0.1 \mathrm{~mol} / \mathrm{L})$ を緑色になるまで混ぜた際に $8 \mathrm{~mL}$ だった結果を 1 : 1.6 という比率にまとめていた。教員は, 「結果の ルーブリックには, どう書かれているかな？」と問 いかけると, 生徒は「観察して, 表・グラフにまと める‥ので, 表で書かないといけない」と発言した。

\begin{tabular}{|c|c|}
\hline [結果] & $\operatorname{mel} / 2): \mathrm{H}_{2} \mathrm{SO}_{\operatorname{map}}(\mathrm{O}$ \\
\hline (1) NaOHaq (0.11 & $5 m L: 4 n L \rightarrow \Rightarrow$ \\
\hline $5 \mathrm{~mL}: 8 \mathrm{~m}$ & $=1 \mathrm{NaOH}+a g\left(0 z^{2 m e l} / 4\right)$ : $H_{-} \mathrm{SO}_{+}(0.2$ \\
\hline$\because \mathrm{HCl}$ aq $(0.2 \mathrm{me} / \mathrm{L})$ & $5 \mathrm{~mL}: 4 \mathrm{~mL} \rightarrow$ 緑 \\
\hline $\begin{array}{l}\vec{\rightarrow} \text { 青色 } \\
\rightarrow \text { 黄色 } \Rightarrow 1=0,5\end{array}$ & (9) Halaq (0.1 mal/i): NaOHaq (OI mol/2) \\
\hline L) : $\mathrm{H}_{2} \mathrm{SO}_{4}$ aq $(0,(\operatorname{mol} / 6)$ & 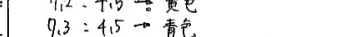 \\
\hline 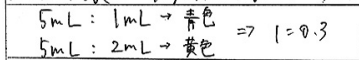 & $\Rightarrow 1: 0.62 \Rightarrow 1.6=1$ \\
\hline (4) $\mathrm{NaOH}_{\text {aq }}(0,1 \mathrm{mal} / \mathrm{L}): \mathrm{H}_{2} \mathrm{SO}_{\text {aqq }}(0,2 \mathrm{mo} / \mathrm{L})$ & $H \log (0.1$ mol $/ \mathrm{L}): \mathrm{Na}_{\text {a.OH }}$ oq $(0.2 \mathrm{~mol} / \mathrm{h})$ \\
\hline 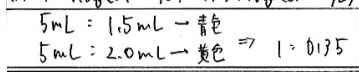 & 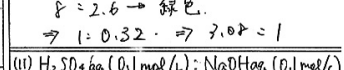 \\
\hline (5) $\mathrm{NaOH} a q(0,2$ mol/L) $: H C l a q(0$. mol/L) & \\
\hline 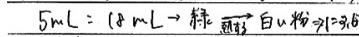 & $\Rightarrow$ \\
\hline (6) $\mathrm{NaOH}+\mathrm{Haq}(0,2 \mathrm{~mol} / \mathrm{L}): \mathrm{HCl}$ aq $(0,2 \mathrm{~mol} / \mathrm{c})$ & 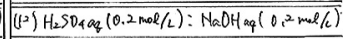 \\
\hline $5 \mathrm{~mL}=4 \mathrm{HL} \rightarrow$ 緑 $\quad \Rightarrow 1=0.8$ & $6=6.8 \rightarrow$ 緑色. \\
\hline
\end{tabular}

図 7 実験報告書の実験結果。結果のルーブリックに基 づいて，表にデータをまとめていた。

これはルーブリックを用いた教員による即時的なア セスメントである証左である。また，このデータを 整理することは，言い換えればこの後の活動におい て，量的関係を議論するために必要なものであると 考えられる。

このように，すべての実験において，結果を表で 記載し, 詳細な数值データとしてまとめる学習活動 は，ルーブリック（表 3）の結果の「表やグラフな どを用いて，結果をわかりやすく記述する事」の記 載内容と合致したものであると捉えられる。なお, 結果のルーブリックによる評価は， A 評価 155 名， B 評価 9 名, $\mathrm{C}$ 評価 1 名（欠席 3 名）であった。

また, 蒸発させる事で出現した結晶についても, 観察の記録として報告書に記されていた。ルーブ リック（表 3）の結果の観点で「実験中の様子を観 察し」が効果的に働いたためである。したがって, 結果の記述において, 上述の学習活動が具現化され たのは，結果のルーブリックを意識したためと考え られる。

\section{4 実験の考察と発表}

4 時間目には, 実験結果のまとめを行った。また, 結果を基に，個人レベルで考察を行い，その後に学 級全体で発表の準備に取り組んだ。

5 時間目は, 各班で，ホワイトボードに実験結果 と考察に関する発表内容についての話し合いを行い, 学級内で発表を行った（図 8)。発表中は, 概ね一つ の班に一つ以上の質問が上り, 質疑応答を適宜行つ ている様子が確認された。

図 8 によると，量的関係を意味する酸・アルカリ を混合させた体積比が赤字で表現されていた。図 8 


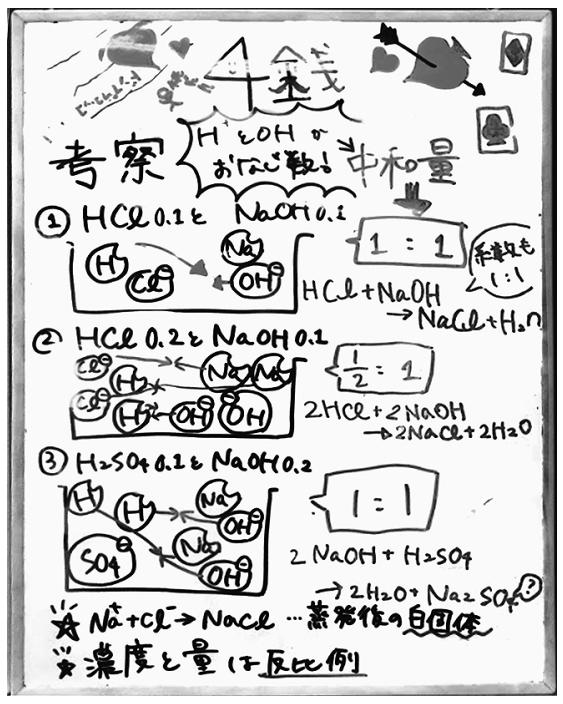

図 8 班で全体発表のためにまとめたホワイトボード (A2 サイズ)。解䣋のルーブリックに基づいて, イオンモデルや図, 化学反応式などを用いて, 中 性になる条件や中和の仕組みを説明していた。

中の (1)同じモル濃度であれば塩酸と水酸化ナトリウ 么水溶液は, 体積比が $1: 1$ で中性になるが, 図 8 中 の(2)塩酸のモル濃度が水酸化ナトリウム水溶液の 2 倍のモル濃度の場合, 体積比が $\frac{1}{2}: 1$ で中性になるこ とを，実験結果を基に考察していた。

また，図 8 から，模式的なビーカーの中において， 水溶液中のイオンを, $\mathrm{H}^{+}, \mathrm{Na}^{+}$の陽イオンはへこみ があり, $\mathrm{Cl}^{-}, \mathrm{OH}^{-}, \mathrm{SO}_{4}{ }^{2-}$ の陰イオンは電子 $(-)$ が ついたモデルで表現していた。水溶液のモル濃度と 混合する体積の関係について，イオンモデルを用い て説明をしていた。イオンの結びつきは, 赤矢印で 説明していた。また, 青字で, 反応前後の物質の変 化を, 化学反応式を用いながら, 係数と体積比が関 係していることを説明していた（図 8)。これは，解 釈のルーブリックにある,「イオンモデルや化学反応 式などを用いて」の部分に相当し, ルーブリックが 学びの具現化に寄与した結果である。

実際の実験結果について, 水溶液中の目に見えな いミクロな世界の理解を, イオンモデルを用いなが ら説明していた。これは, 中和の仕組みや中性にな る条件に, 化学反応式の係数や体積, モル濃度と いった量的関係を用いて議論しているため, 解釈の ルーブリックの後半部分（「中和の仕組みや量的関係 を十分に説明できる」）が十分に達成されたものと判 断され，ルーブリックが班ごとの発表にも, 寄与し ていた。

\section{5 実験の解釈のまとめ}

図 9 は, 発表後の生徒が実験報告書に書いた解釈 のまとめである。まず，中和は水と塩ができること であり, 中性になる条件として, 水素イオンと水酸 化物イオンの数によって決まることを示していた。 特に, 図 9 右上部では塩酸 $\mathrm{HCl}$, 図 9 右下部では硫 酸 $\mathrm{H}_{2} \mathrm{SO}_{4}$ について, 水溶液中で電離した際の水素イ オンの数 (価数) が具体的に示されていた。

図 9 から，ビーカー内部の目に見えないミクロな 世界についてイオンモデルを用いて可視化していた ため，解釈のルーブリックの前半部分（「イオンモデ ルや化学反応式などを用いて」）が達成できていた。

その上で，中性になる時の量的関係の説明には, イオンモデルを用いて，図示しながら説明していた。 中性になる条件は，「体積 $\times$ モル濃度 $\times$ 価数」という 量が重要になることを，イオンモデルで説明できて おり，ミクロな世界の定式化にも成功し，科学概念 が構築されたことは明らかである。すなわち，解釈 のルーブリックの後半部分「中和の仕組みや量的関 係を十分に説明できる」が十分に達成できた。これ は言い換えると，実験の目的の達成ができた。

つまり，ルーブリック（表 3）の解釈の観点にお いて, 科学概念を形成するための生徒の学習活動を 教員が支援したことの証左である。生徒はルーブ リックについて学びを進めるための指針として捉え, 結果, 問題解決的な学習が具現化され, 科学概念が 獲得できたと考えられる。なお，解釈のルーブリッ クによる評価は， $\mathrm{A}$ 評価 119 名， B 評価 37 名， C 評

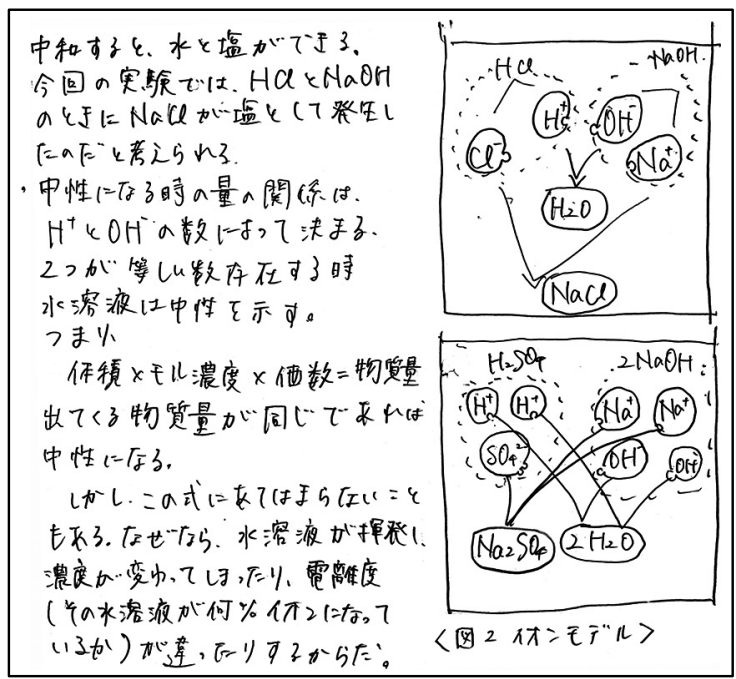

図 9 実験報告書の解釈のまとめ。解釈のルーブリック を十分に達成していた。 
価 9 名（欠席 3 名）であった。

実験報告書の計画・結果・解釈の記述分析から, 回収箱モデルによって作成されたルーブリックが, 生徒の学習活動に対して学習の足がかりや活動の指 針となっていたことが明らかになった。このように， 実際の授業において, ルーブリックを用いた問題解 決的な学習を十全に実施し, 科学概念の構築が生徒 の作成したポートフォリオから読み取ることができ たため, 主体的・対話的で深い学びが具現化された と捉えられる。

\section{6. 質問紙調査}

生徒が計画・結果・解釈の各場面において, ルー ブリックをどの程度意識していたかの調査をするた めに, 5 時間目終了後に実際に連続したすべての授 業に出席した生徒数 154 名を対象にした質問紙調査 を実施した。

質問は，大きく二つ（質問(1)，質問(2)）設定した。 質問(1)「各学習場面におけるルーブリックを意識し たかについて」，1を「できなかった」，4を「できた」 とした 1 から 4 の数字を用いた四件法を適用し回答 させた。表 4 は, 質問項目と統計処理（直接確率検 定）をそれぞれ示したものである。これらのデータ において, $4 \cdot 3$ 点を肯定的回答, $2 \cdot 1$ 点を否定的回 答として，フィッシャーの直接確率検定を行った。 また, 質問(2)「ルーブリック作成についての生徒に とっての今後の意向」については, 自由記述方式で 回答させた。

\section{1 質問(1)の結果と分析}

質問(1)，生徒が各学習場面におけるルーブリッ クを意識して取り組んだかについての調査で, いず れの項目 (学習過程) においても, 直接確率検定 (両 側検定）で，有意な差が見受けられた（p<0.05）。

表 4 質問紙調査質問(1)各学習段階でのルーブリックの 意識に関する結果 $(N=154$, * $\mathrm{p}<0.05$ を意 味する)

\begin{tabular}{|c|l|c|c|c|}
\hline 番号 & \multicolumn{1}{|c|}{ 質問内容 } & 肯定 & 否定 & 検定 \\
\hline 1 & 仮説・計画の立案 & $\begin{array}{c}133 \text { 人 } \\
(86 \%)\end{array}$ & $\begin{array}{c}21 \text { 人 } \\
(14 \%)\end{array}$ & $*$ \\
\hline 2 & 実験・結果のまとめ & $\begin{array}{c}98 \text { 人 } \\
(63 \%)\end{array}$ & $\begin{array}{c}57 \text { 人 } \\
(37 \%)\end{array}$ & $*$ \\
\hline 3 & 考察と発表 & $\begin{array}{c}126 \text { 人 } \\
(81 \%)\end{array}$ & $\begin{array}{c}28 \text { 人 } \\
(19 \%)\end{array}$ & $*$ \\
\hline \multirow{2}{*}{4} & 解釈のまとめ & $\begin{array}{c}145 \text { 人 } \\
(94 \%)\end{array}$ & $\begin{array}{c}9 \text { 人 } \\
(6 \%)\end{array}$ & $*$ \\
\hline
\end{tabular}

生徒は, 仮説・計画の作成, 考察と発表, 解釈のま とめ中など，さまざまなパフォーマンスの場面にお いて肯定が多数を占めた。

この中で, 肯定的回答が最も少なかったのは,「2 実験・結果のまとめ」の項目であった（肯定 $63 \% ） 。$ これは，実験・結果をまとめる場面に打いては，生 徒自身が集中して学習に取り組み, 作業の時間が多 くなり，ルーブリックに対しては，ある程度意識し ていることが明らかになった。

また，解釈のまとめを行うときには，肯定的回答 が多く，自身での対話活動時にルーブリックを特に 意識することがわかった。したがって，回収箱モデ ルで作成したルーブリックが問題解決的学習に有効 であることが示された。

\section{2 質問(2)の結果と分析}

ここでは，質問(2)「ルーブリック作成についての 生徒にとっての今後の意向」についての自由記述の 回答の分析について言及する。具体的には，「授業で は今後も解釈の要点を作成しながら学習を進めたい と思いますか？」と問うた。これに対し，肯定的言 及が 120 人 $(78.0 \%)$, 否定的言及が 19 人 $(12.3 \%)$, その他 15 人 $(9.7 \%)$ であった。

これらの質問に対する肯定的言及のうち約 8 割が, 「学習を進めやすい」,「学習の見通しを持つことがで きた」，「自分たちでルーブリックを作成することで, 内容理解の実感をしながら学習に取り組むことがで きた」というコメントだった。これは，スティーブン ス\&レヴィ（2014）が, ルーブリックの使用が，生徒 の学習に対する主体性の認識を強化するという報告 と軌を一にする。

一方で，否定的言及の多くは，「ルーブリックを作 成するのが難しい」という作成に対する難度に関す る意見だった。スティーブンス\&レヴィ（2014）で は，生徒にルーブリックを作成させるためには，提 示モデルなどによる経験が重要である。また, 回収 箱モデルでの作成においても，その作成回数を重ね る重要性が示唆された。

また，同質問(2ににおいて，「押しつけられたルーブ リックではないため，実験などのモチベーションが 向上した」という趣旨の記述も散見された。森本ら （2014）の報告の通り，教員が一方的に提示するルー ブリックではなく, 教員・生徒全体で作成を通じて 共有化することで，合意形成を図ることができたた めである。 


\section{7. 本研究の結論}

本研究では, 中学校理科の授業において, 教員と 生徒が回収箱モデルを用いてルーブリックを作成す る視点を明らかにした。

ルーブリック作成を取り入れた授業実践を分析し た結果，教員と生徒の間で双方向的に取り組む回収 箱モデルを用いて, 教員と生徒で共有化されたルー ブリックを作成することができた。また，計画・結 果・解釈の生徒の各学習場面において, 生徒は学習 活動に見通しを持って学習に取り組み，最終的には 科学概念が構築されたことが示された。回収箱モデ ルを用いてルーブリックを作成し，パフォーマンス 評価に用いることは, 生徒の目的的な学習活動を支 援し, 主体的・対話的で深い学びの具現化に寄与す ることが明らかになった。

\section{謝辞}

本論文は, 慶應義塾湘南藤沢中等部 27 期生と試行 錯誤しながら臨んだ授業実践研究である。実際の授 業では生徒は熱心に取り組んでいた。また, 本研究 には様々な方に多大な協力をいただいた。関係者の 皆様に感謝申し上げる。

\section{引用文献}

Gipps, C.V. (1994). Beyond Testing: Towards a Theory of Educational Assessment, The Falmer Press, 172-176.

鈴木雅之（2011）「ルーブリックの提示による評価基準・評 価目的の教示が子どもに及ほすす影響一テスト観・動機 付け・学習方略に着目して一」『教育心理学研究』第 59 卷, 131-143.

鈴木一成（2014）「子どもの思考と表現の育成に寄与する理 科授業デザインとパフォーマンス評価に関する研究」 博士論文 (東京学芸大学大学院), 130-140.

鈴木一成（2019）「学習指導要領における理科授業をデザイ
ンする枠組みについての一考察「科学的に探究する 力」を育成する理科授業デザイン一」『東洋大学紀要』 第 72 集，59-67.

スティーブンス，D. D. \&レヴィ，A.J.（2014）『大学教員の ためのルーブリック評価入門』玉川大学出版部。

竹田大樹・鈴木一成（2020）「主体的・対話的で哚い学びを 具現化する視点に関する研究一積雲高度測定実験にお ける理科授業デザインの実践一」『慶應義塾大学日吉 紀要自然科学』第 67 巻, 17-33.

塚本泰平・清水誠（2006）「ルーブリックを教師と生徒で作 成する効果一体細胞分裂の観察を事例に一」『埼玉大 学紀要教育学部 (教育科学)』第 55 卷, 第 1 号, 1-6.

寺嶋浩介・林朋美（2006）「ルーブリックの構築により自己 評価を促す問題解決学習の開発」『京都大学教育研究』 第 12 卷, 63-71.

Perkins, D.N., Crismond, D., Simmons, R., \& Unger, C. (1995). Inside Understanding software goes to school: Teaching for understanding with new technologies, pp. 70-84, Oxford University.

松下佳代（2007）「パフォーマンス評価一子どもの思考と表 現を評価する一」『日本標準』, 1-69.

森本信也・鈴木一成・渡辺理文・松本朱実 (2014)「現代的 な教育課題にそくした理科学習指導と評価の視点」 『横浜国立大学教育人間科学部紀要横浜国立大学教育 人間科学部編』第 16 号, 155-173.

文部科学省（2017）『中学校学習指導要領（平成 29 年告 示）解説理科編」Retrieved from https://www.mext.go.jp/ component/a menu/education/micro detail/_ icsFiles/ afieldfile/2019/03/18/1387018 005.pdf (accessed 2020. 04.13)

渡辺理文・森本信也・小湊清隆（2016）「理科授業における 資質・能力の育成を促す学習環境のデサインの分析」 『理科教育学研究』第 56 巻, 第 4 号, 469-480.

(2020 年 4 月 15 日受付, 2020 年 10 月 27 日受理) 


\title{
Elaboration on the Proactive, Interactive, and Deep Learning Perspective: Constructing Rubrics using a "Pass-the-Hat" Model
}

\author{
Hiroki TAKEDA ${ }^{1}$, Issey SUZUKI ${ }^{2}$ \\ ${ }^{1}$ Keio Shonan Fujisawa Junior and Senior High School \\ ${ }^{2}$ Toyo University
}

\begin{abstract}
SUMMARY
Previous studies have pointed out that it is important for lower secondary school science lessons to aim for purposeful learning activities based on the Investigational Activity Process in order for pupils to realize Proactive, Interactive, and Deep Learning successfully. We analyzed several studies which pointed out that utilizing rubrics to drive learning activities is one of many valid tools in constructing and practicing effective science lessons. In this study, teachers and children collaborated on constructing rubrics in a junior high school science lesson. We used a "Pass-the-Hat" model to construct shared rubrics as proposed by Stevens and Levi (2014). In practice, the effectiveness of the lesson confirmed that the rubrics created by teachers and children in collaboration can be a model case of evaluation that indeed contributes to the students' successful realization of Proactive, Interactive, and Deep Learning.
\end{abstract}

$<$ Key words $>$ Rubric, Pass-the-Hat Model, Proactive, Interactive, and Deep Learning 